\title{
Front Matter: Volume 9805
}

, "Front Matter: Volume 9805," Proc. SPIE 9805, Health Monitoring of Structural and Biological Systems 2016, 980501 (5 May 2016); doi: 10.1117/12.2229280

SPIE Event: SPIE Smart Structures and Materials + Nondestructive Evaluation and Health Monitoring, 2016, Las Vegas, Nevada, United States 


\section{PRO CEEDINGS OF SPIE}

\section{Health Monitoring of Struc tural and Biological Systems 2016}

\section{Tíbikram Kundu}

Editor

\section{1-24 March 2016 \\ Las Vegas, Nevada, United States}

Sponsored by

SPIE

Co-sponsored by

Polytec, Inc. (United Sta tes) OZO ptic s, Ltd. (United Sta tes) • APS Dyna mics, Inc. (United States) - The ElectroForce Systems G roup of TA Electroforce Corporation (United States) - The Institute of Physic s (United Kingdom) • Americ a n Elements (United Sta tes)

Cooperating Organizations

Intelligent Materia Is Forum ( a pan)

J et Propulsion Laboratory (United Sta tes)

National Science Foundation (United States)

Published by

SPIE 
The papers in this volume were part of the technical conference cited on the cover and title page. Papers were selected and subject to review by the editors and conference program committee. Some conference presentations may not be available for publication. Additional papers and presentation recordings may be available online in the SPIE Digital Library at SPIEDigitallibrary.org.

The papers reflect the work and thoughts of the authors and are published herein as submitted. The publisher is not responsible for the validity of the information or for any outcomes resulting from reliance thereon.

Please use the following format to cite material from these proceedings:

Author(s), "Title of Paper," in Health Monitoring of Structural and Biological Systems 2016, edited by Tribikram Kundu, Proceedings of SPIE Vol. 9805 (SPIE, Bellingham, WA, 2016) Six-digit Article CID Number.

ISSN: 0277-786X

ISSN: 1996-756X (electronic)

ISBN: 9781510600461

Published by

SPIE

P.O. Box 10, Bellingham, Washington 98227-0010 USA

Telephone +1 3606763290 (Pacific Time) · Fax +1 3606471445

SPIE.org

Copyright (C) 2016, Society of Photo-Optical Instrumentation Engineers.

Copying of material in this book for internal or personal use, or for the internal or personal use of specific clients, beyond the fair use provisions granted by the U.S. Copyright Law is authorized by SPIE subject to payment of copying fees. The Transactional Reporting Service base fee for this volume is $\$ 18.00$ per article (or portion thereof), which should be paid directly to the Copyright Clearance Center (CCC), 222 Rosewood Drive, Danvers, MA 01923. Payment may also be made electronically through CCC Online at copyright.com. Other copying for republication, resale, advertising or promotion, or any form of systematic or multiple reproduction of any material in this book is prohibited except with permission in writing from the publisher. The CCC fee code is 0277-786X/16/\$18.00.

Printed in the United States of America.

Publication of record for individual papers is online in the SPIE Digital Library.

\section{SPIE. DIGITAL}

Paper Numbering: Proceedings of SPIE follow an e-First publication model. A unique citation identifier (CID) number is assigned to each article at the time of publication. Utilization of CIDs allows articles to be fully citable as soon as they are published online, and connects the same identifier to all online and print versions of the publication. SPIE uses a six-digit CID article numbering system structured as follows:

- The first four digits correspond to the SPIE volume number.

- The last two digits indicate publication order within the volume using a Base 36 numbering system employing both numerals and letters. These two-number sets start with $00,01,02,03,04$, $05,06,07,08,09,0 A, 0 B \ldots$ OZ, followed by 10-1Z, 20-2Z, etc. The CID Number appears on each page of the manuscript. 


\title{
Contents
}

\author{
ix Authors \\ xi Conference Committee \\ XV Introduction
}

GUIDED WAVE FOR COMPOSTIE INSPECTION

980502 Characterization of propagation and scattering via wavefield imaging for improved in situ imaging of damage in composites [9805-1]

980503 Numerical and experimental studies of delamination detection in short fiber reinforced composites using Lamb waves [9805-2]

980504 Model assisted probability of detection fora guided waves based SHM technique [9805-3]

980505 Phased aray beamforming and imaging in composite laminates using guided waves [9805-4]

BRIDGE MONITORING

980507 Damage detection based on mode shapes of a girder bridge constructed from responses of a moving vehic le under impact excitation [9805-6]

980508 Structural health monitoring system of Ironton-Russell bridge during substructure construction [9805-7]

9805 OA Numerical simulation of wind effects on the temperature analysis of bridges [9805-9]

\section{BUILDING AND BRIDGE MONITORING}

9805 OB Sparse generalized pencil of function and its application to system identific ation and struc tural health monitoring [9805-10]

9805 0C Uncertainty analysis of practical structural health monitoring systems cumently employed for tall buildings consisting of small number of sensors [9805-11]

9805 OD Bayesian model updating using incomplete modal data without mode matching [9805-12]

9805 OE Gap between technically accurate information and socially appropriate information for structural health monitoring system installed into tall buildings [9805-13] 
9805 OF Estimation of seismic response of buildings with a few accelerometers without input data [9805-14]

\section{ACOUSTIC SOURCE LOCAUZATION}

9805 ol Acoustic emission source localization based on distance domain signal representation [9805-17]

9805 0J Acoustic source localization in an anisotropic plate without knowing its material properties: a new approach [9805-18]

NONUNEAR GUIDED WAVE BASED TECHNIQUES

9805 OK Amplitude-dependent contraction/ elongation of nonlinear Lamb waves [9805-19]

$9805 \mathrm{OL}$ Analytical modeling of contact acoustic nonlineanity of guided waves and its application to evaluating seventy of fatigue damage [9805-20]

9805 OM Progressive damage state evolution and quantification in composites [9805-21]

MODEUNG WAVE PROPAGATION AND CRACK PROPAGATION

9805 ON Modeling of fatigue crack induced nonlinear ultrasonics using a highly parallelized explicit local interaction simulation approach [9805-23]

980500 Defect induced guided waves mode conversion [9805-24]

9805 OP Crack propagation modeling using Peridynamic theory [9805-25]

$98050 \mathrm{Q}$ Simulation of guided wave propagation near numerical Brillouin zones [9805-26]

\section{GUIDED WAVES FOR SHM}

9805 OS Finite element modeling of guided wave scattering at delaminations in composite panels [9805-28]

9805 0T Helical guided waves in liquid-filled cylindrical shells subjected to static pressurization stress [9805-29]

9805 OU A hybrid non-reflective boundary tec hnique for efficient simulation of guided waves using local interaction simulation approach [9805-30]

9805 OV Detecting delaminations and disbondings on full-scale wing composite panel by guided waves based SHM system [9805-31] 
9805 0X Higherand sub-hamonic Lamb wave mode generation due to debond-induced contact nonlinearity [9805-35]

9805 oY Consolidating guided wave simulations and expenimental data: a dictionary leaming approach [9805-106]

PIPES AND TUBES

980510 In-situ measurement of the height of condensed water in steam pipes with dynamic flow [9805-36]

980511 Advanced signal processing technique for damage detection in steel tubes [9805-37]

NONUNEAR TECHNIQUES

980512 Assessment of the aging level of rejuvenated hot mixed asphalt conc rete pavements [9805-38]

980513 Wideband excitation in nonlinear vibro-acoustic modulation for damage detection [9805-39]

980514 Damage visualization using synchronized noncontact laser ultrasonic scanning [9805-40]

980515 A semi-nonlocal numerical approach for modeling of temperature-dependent crackwave interaction [9805-41]

PERIODIC STRUCTURE AND METAMATERIAL II

9805 IF Anomalous refraction of guided waves via embedded acoustic metasurfaces [9805-53]

9805 1l Mechanically robust mic rofluidics and bulk wave acoustics to sort mic ropartic les [9805-49]

ACOUSTIC EMISSION BASED SHM

9805 1] Identifying fatigue crack geometric features from acoustic emission signals [9805-56]

9805 IK Embedded and conventional ultrasonic sensors for monitoning acoustic emission during thermal fatigue [9805-57]

\section{SIGNAL PROC ESSING AND DAMAGE DETECTION}

9805 IN Probabilistic uncertainty quantification of wavelet-transform-based structural health monitoring features [9805-60]

$98051 \mathrm{~A}$ A novel defect detection technique based on automatic detection of potential background [9805-63] 
9805 IR Study on electromechanical impedance characteristics of part of structures made of CRP [9805-64]

9805 1S Rapid evaluation of mechanical boundary conditions using impedance based structural health monitoring [9805-65]

9805 1T Development of novel general equation for multistage epic yc lic gearset with comected teeth: fixed-speed approach [9805-66]

$98051 \mathrm{U}$ Venification of recursive probabilistic integration (RPI) method for fatigue life management using non-destruc tive inspections [9805-67]

\section{INNOVATIVE SENSING AND NOVELINSTRUMENTS}

9805 IV Stochastic global identification of a bio-inspired self-sensing composite UAV wing via wind tunnel experiments [9805-68]

$98051 X$ Sensing human physiological response using wearable carbon nanotube-based fabrics [9805-70]

9805 IY Fiber optic sensor for flow and visc osity measurement [9805-71]

$98051 Z$ Ultrasonic inspection of multiple-rivet-hole lap joint cracks using global analysis with local finite element approach [9805-113]

USE OF SENSOR TECHNOLOGIES FOR CONDITION ASSESSMENTOF HIGHMAY INFASTRUCTURE

980520 A curvature based approach using long-gage fiber optic sensors [9805-73]

980521 Identification of steady-state uniform temperature distributions to facilitate a temperature driven method of Structural Health Monitoring [9805-74]

980522 Field testing of Martlet wireless sensing system on an in-senice pre-stressed concrete highway bridge [9805-75]

980523 Validation of long-term measurements from \#G sensors [9805-76]

980524 Identification of minute damage in composite bridge structures equipped with fiber optic sensors using the location of neutral axis and finite element analysis [9805-77]

NOVE INSTRUMENTS AND INNOVATIVE SENSING

980525 Effects of asphalt rejuvenator on themal and mechanical properties on oxidized hot mixed asphalt pavements [9805-78] 
980526 Reflective SOA fiber cavity adaptive laser source for measuring dynamic strains [9805-79]

980527 Ultrasonic imaging using wave structure-based weights and global matched coefficients [9805-80]

980528 Performing modal analysis for multi-metric measurements: a disc ussion [9805-81]

980529 Undenwater camera with depth measurement [9805-82]

9805 2A Photonic crystal fiber based chloride chemical sensors for comosion monitoring [9805-84]

9805 2B Nonlinear phased array imaging [9805-85]

9805 2C Piezoelectric-based smart sensing system for I-beam structural health monitoring [9805-83]

NDE AND RAPID GLOBALASSESSMENTOF HIG HMAY BRIDGES

9805 2D Low-cost, quantitative assessment of highway bridges through the use of unmanned aerial vehic les [9805-86]

9805 2G Companison of air-coupled GPR data analysis results determined by multiple analysts [9805-90]

$98052 \mathrm{H}$ Similanities and differences in bare concrete deck deterioration curves from multi NDE technology surveys [9805-91]

\section{POSTER SESSION}

9805 2K Long-term monitoring of structures through point c loud analysis [9805-94]

$98052 \mathrm{~L}$ Multi-field coupled sensing network for health monitoring of composite bolted joint [9805-95]

9805 2M The application of data mining and cloud computing techniques in data-driven models for structural health monitoring [9805-96]

9805 2N Fabrication and characterization of nanostructured Mg-doped CdS/AAO nanoporous membrane for sensing applications [9805-97]

980520 Rotor damage detection by using piezoelectric impedance [9805-98]

9805 2P Optimized sensor location for estimating story-drift angle for tall buildings subject to earthquakes [9805-99]

$98052 \mathrm{Q}$ The random field model of the spatial distribution of heavy vehicle loads on long-span bridges [9805-100]

$98052 R \quad$ Wave propagation in metamaterial lattice sandwich plates [9805-101] 
$98052 \mathrm{~T}$ Effect of tubing material on conventional and thin BG sensor for embedded environment impact monitoring of CRP composites [9805-105]

$98052 \mathrm{U}$ Geometry control of long-span continuous girder concrete bridge during construction through finite element model updating [9805-107]

9805 2W Early age monitoring of cement mortar using embedded piezoelectric sensors [9805-109]

$98052 X \quad$ Finite element modelling of non-bonded piezo sensors for biomedical health monitoring of bones based on EMI technique [9805-110]

980530 Small-strain measurement in bridge connections using the digital image comelation (DIC) technique [9805-112] 


\section{Authors}

Numbers in the index correspond to the last two digits of the six-digit citation identifier (CID) article numbering system used in Proceedings of SPIE. The first four digits reflect the volume number. Base 36 numbering is employed for the last two digits and indicates the order of articles within the volume. Numbers start with 00, 01, 02, 03, 04, 05, 06, 07, 08, 09, OA, OB...0Z, followed by 10-12, 20-2Z, etc.

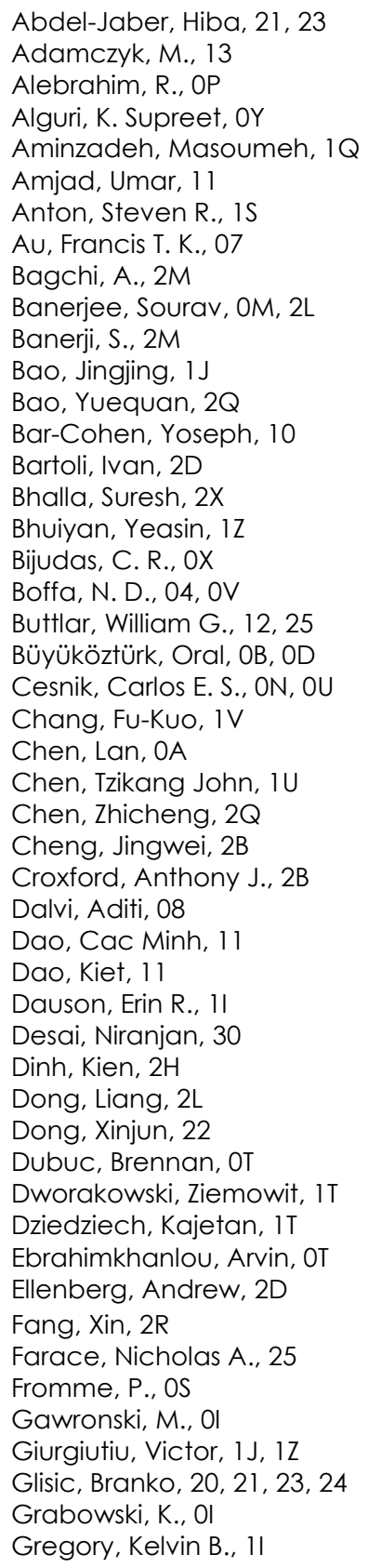

Greve, David W., 11

Gucunski, Nenad, 2H

Guha, Anurup, OX

Gupta, Ashok, 2X

Hafezi, M. H., OP

Hamdy, Hany, 2N

Harley, Joel B., OY

Healy, Gregory P., 11

Helmicki, Arthur, 08

Hirai, Kenta, OC

Hu, Min-yi, $2 \mathrm{U}$

Hunt, Victor, 08

Jablonski, Adam, $1 \mathrm{~T}$

Jafari, Bahman, 2K

Ji, Jing, $O A$

Kettle, Ryan A., $1 S$

Khaloo, Ali, 2K

Khazaeli, S., 2M

Kijanka, Piotr, 0Q, 15, $1 T$

Kim, Chun-Gon, 2T

Kim, Jin-Hyuk, 2T

Kim, Jinyoung, $2 \mathrm{H}$

Klepka, A., 13

Kliewer, Kaitlyn, 20

Kontsos, Antonios, 2D

Koo, Helen S., $1 X$

Kopsaftopoulos, Fotios, $1 \mathrm{~V}$

Krishnaswamy, Sridhar, 26, 2A

Kudela, Pawel, 03, 00

Kundu, Tribikram, OJ, OP, 11

Kurfess, Thomas, 1Q

Kwon, Heejung, 2T

Kwon, Hyunseok, 2T

Lanza di Scalea, Francesco, 27

Lattanzi, David, 2K

Leamy, Michael J., OK

Leang, Jonathan, 1Y, 29

Leckey, Cara A. C., 05

Lee, Hyeong Jae, 10

$\mathrm{Li}$, Fengwu, OA

Li, Hui, 2Q

Li, Jian, $2 \mathrm{U}$

$\mathrm{Li}, \mathrm{Xi}, 24$

Li, Yu-Hung, IV

Lih, Shyh-Shiuh, 10

Lin, Keng-Ren, 29

Liu, Peipei, 14

Liu, Xi, 22

Loh, Kenneth J., $1 \mathrm{X}$ 
Madan, Alok, $2 X$

Maio, L., 04, OV

Majewska, K., 28

Malinowski, Paweł H., 00, $1 \mathrm{R}$

Mao, Y. F., 20

Mao, Zhu, IN

Martino, Nicole, $2 \mathrm{G}$

Martowicz, Adam, 15

Maser, Ken, $2 \mathrm{G}$

McGovern, Megan, 12

Memmolo, V., 04, OV

Michaels, Jennifer E., 02

Michaels, Thomas E., 02

Mita, Akira, OC, OE, OF, 2P

Mohammadi-Ghazi, Reza, OB

Monaco, E., 04, OV

Moon, Franklin, 2D

Murat, B. I. S., OS

Mustafa, Mona, 2N

Narayanan, Arun, 2W

Nardari, Raphael, IV

Nguyen, Thompson Vu, 27

Norouzi, Mehdi, 08

Oppenheim, Irving J., 11

Ostachowicz, Wiesław M., 03, 00, 1R, 28

Ozawa, Sayuki, 2P

Packo, Pawel, OI, OJ, OK, OQ

Park, Won Hyun, OJ

Park, Yurim, 2T

Patra, Subir, OM

Pieczonka, L., 13

Poddar, Banibrata, $1 \mathrm{~J}$

Potter, Jack N., 2B

Qi, Zhongqiang, 07

Qin, Y., 20

Qing, Xinlin, 2L

Radzienski, Maciej, 03, 28

Ravandi, A. G., 2M

Reilly, J., 21

Reis, Henrique, 12, 25

Ricci, F., 04, OV

Russek, P., 01

Salamone, Salvatore, OT

Sarrafi, Aral, IN

Schipf, David, 29

Semperlotti, Fabio, $1 \mathrm{~F}$

Shaban, Mohamed, 2N

Shen, Yanfeng, ON, $1 Z$

Shiao, Michael, $1 \mathrm{U}$

Shrestha, Pratik, 2T

Sohn, Hoon, 14

Soman, R., 28

Srivastava, Shashank, $2 X$

Staszewski, Wieslaw J., OI, OK, OQ, 13, 15

Sternini, Simone, 27

Su, Zhongqing, $\mathrm{OL}$

Subramaniam, Kolluru V. L., $2 \mathrm{~W}$

Sun, Hao, OD

Sunarsa, Timotius Yonathan, 14

Suzuki, Yu, OF
Tao, Chuanyi, 26, 2A

Tao, Y., 20

Tian, Zhenhua, 05

Trujillo, Blaine, $1 \mathrm{~K}$

Tsui, Chi L., 29

Uhl, Tadeusz, OI, OK, $1 \mathrm{~T}$

Wandowski, Tomasz, 00, 1R

Wang, Kai, OL

Wang, Long, $1 \mathrm{X}$

Wang, Pengchuan, IV

Wang, Wei-Chih, 1Y, 29

Wang, Xingwei, 2C

Wang, Yang, 22

Wang, Yishou, $2 \mathrm{~L}$

Wei, Heming, 26, 2A

Wen, Jihong, 2R

Williams, Westin B., 02

Wu, Jie, $2 U$

Yadav, Susheel Kumar, 11

Yan, Quan-sheng, $2 U$

Yarnold, M., 21

Yin, Jianfei, 2R

$Y U$, Dianlong, $2 R$

Yu, Lingyu, 05

Yu, Tzuyang, 2C

Zagrai, Andrei, $1 \mathrm{~K}$

Zhang, Chen, $2 \mathrm{C}$

Zhang, Haifeng, 2C

Zhang, Hui, OU

Zhou, Linren, OA

Zhu, Hongfei, $1 \mathrm{~F}$ 


\section{Conference Committee}

Symposium Chairs

Jayanth N. Kudva, NextGen Aerona utic s, Inc . (United States)

Theodoros E. Matikas, University of loannina (Greece)

Symposium Co-chairs

Thibikram Kundu, The University of Arizona (United States)

Gregory W. Reich, Air Force Resea rch Laboratory (United States)

Conference Chair

Tribikram Kundu, The University of Arizona (United States)

Conference Co-chair

Wolfgang Grill, Universität Leipzig (Germany)

Conference Program Committee

Sourav Banerjee, University of So uth Ca rolina (United States)

Yoseph Bar-Cohen, J et Propulsion Laboratory (United States)

Fu-Kuo Chang, Stanford University (United States)

Anthony J. Croxford, University of Bristol (United King dom)

Paul Fromme, University College Lond on (United Kingdom)

Vic tor Giurgiutiu, University of So uth Ca rolina (United States)

Srinivasan Gopalakrishnan, Indian Institute of Science (India)

Daniel J . Guyomar, Institut National des Sc ienc es Appliquées de Lyon (France)

Guoliang Huang, University of Misso uri School of Medic ine

(United States)

Xiaoning Jiang, North Ca rolina State University (United States)

Sridhar Krishnaswamy, Northwestem University (United States)

Francesco Lanza di Scalea, University of Ca lifomia, San Diego (United States)

Jerome P. Lynch, University of Michigan (United States)

Jennifer E. Mic haels, Georgia Institute of Technology (United States)

Won-Bae Na, Pukyong National University (Korea, Republic of)

Christopher Niezrec ki, University of Massa c husetts Lowell

(United States)

Wieslaw M. Ostachowicz, The Szewa Iski Institute of Fluid-Flow

Machinery (Poland)

Pemgjin F. Pai, University of Misso uri-Columbia (United States) 
Xinlin Qing, Commerc ial Airc raft Comporation of China, Ltd. (China)

Hennique L Reis, University of Illino is at Urbana-Cha mpa ign

(United States)

Pienvincenzo Rizzo, University of Pittsburgh (United States)

Hoon Sohn, KAIST (Korea, Republic of)

Wieslaw J. Staszewski, AGH University of Sc ience and Technology (Poland)

Zhongqing Su, The Hong Kong Polytechnic University (Hong Kong, China)

Nobuo Takeda, The University of Tokyo (J a pan)

Michael D. Todd, University of Califomia, San Diego (United States)

Tadeusz Uhl, AG H University of Sc ience and Technology (Poland)

Wei-Chih Wang, University of Washington (United States)

J inkyu Yang, University of Wa shington (United States)

Lingyu Yu, University of South Carolina (United States)

Andrei N. Zagrai, New Mexico Institute of Mining and Technology (United States)

George Zentai, Varian Medic al Systems, Inc . (United States)

\section{Session Chairs}

1 Guided Wave for Composite Inspection

Tribikram Kundu, The University of Arizona (United States)

Wolfgang Grill, ASI Ana log Speed Instruments G mbH (Gemany)

2 Bridge Monitoring

Henrique L Reis, University of Illino is at Urba na-Cha mpa ign (United States)

3 Building and Bridge Monitoring

Zhongqing Su, The Hong Kong Polytechnic University (Hong Kong, China)

Lingyu Yu, University of South Carolina (United States)

4 Acoustic Source Localization

Lingyu Yu, University of So uth Carolina (United States)

Paul Fromme, University College London (United Kingdom)

5 Nonlinear Guided Wave Based Techniques

Paul Fromme, University College Lond on (United Kingdom)

Christopher Niezrec ki, University of Massa c husetts Lowell

(United States)

6 Modeling Wave Propagation and Crack Propagation

Tadeusz Uhl, AG H University of Sc ience and Technology (Poland)

Sourav Banerjee, University of So uth Ca rolina (United States) 
7 Guided Waves for SHM

Wieslaw M. Ostachowicz, The Szewa Iski Institute of Fluid-Flow

Machinery (Poland)

Niranjan Desai, Purdue University (United States)

8 Pipesand Tubes

Hoon Sohn, KAIST (Korea, Republic of)

Andrei N. Zagrai, New Mexico Institute of Mining and Technology (United States)

9 NonlinearTechniques

Vic tor Giurgiutiu, University of So uth Ca rolina (United Sta tes)

Hoon Sohn, KAIST (Korea, Republic of)

10 Periodic Structure and Metamaterial I

Guoliang Huang, University of Misso uri School of Medic ine (United States)

J inkyu Yang, University of Wa shington (United States)

11 Periodic Structure and Metamaterial II

J inkyu Yang, University of Wa shington (United States)

Guoliang Huang, University of Misso uri School of Medic ine (United States)

12A Acoustic Emission Ba sed SHM

Anthony J. Croxford, University of Bristol (United King dom)

12B Composite Monitoring

Wieslaw M. Ostac howicz, The Szewa Iski Institute of Fluid-Flow Machinery (Poland)

S. Gopalakrishnan, Indian Institute of Science (India)

13A Signal Processing and Damage Detection

Andrei N. Zagrai, New Mexico Institute of Mining and Technology (United States)

Harsh K. Baid, AlphaSTAR Corp. (United States)

13B Practical Considerations of SHM

Zhenhua Tian, University of So uth Ca rolina (United States)

14A Innovative Sensing and Novel Instruments

Wolfgang Grill, ASI Ana log Speed Instruments GmbH (Germany)

Xiaoning J iang, North Ca rolina State University (United States) 
14B Use of Sensor Tec hnologies for Condition Assessment of Highway Infra struc ture

David D. Mascareñas, Los Alamos National Laboratories

(United States)

15A Novel Instruments and Innovative Sensing

Henrique L Reis, University of Illino is at Urba na-Champaign

(United States)

15B NDE and Rapid Global Assessment of Highway Bridges

Nic ole Martino, Roger Willia ms University (United States) 


\section{Introduction}

In 2001, the SPIE conference (\#4335) on Health Monitoring of Structural and Biological Systems brought engineers, materials scientists, medical doctors, and biologists together to exchange their ideas on this important topic. After having a positive experience at that conference, annual conferences were organized on the same topic. The proceedings of conference 9805 contains papers presented at the 2016 conference. Papers presented in the earlier conferences can be found in the following proceedings volumes: \#4335 (2001), \#4702 (2002), \#5047 (2003), \#5394 (2004), \#5768 (2005), \#6177 (2006), \#6532 (2007), \#6935 (2008), \#7295 (2009), \#7650 (2010), \#7984 (2011), \#8348 (2012), \#8695(2013), \#9064(2014) and \#9438 (2015).

This conference aims to recognize that nondestructive sensing, sensor array design, signal acquisition and transmission, signal processing, energy harvesting etc. are integral parts of health monitoring for both structural and biological systems. I believe that biological and physical science communities are learning from one another by coming to this conference and exchanging ideas. Some of the recent advances in the science and technology of health monitoring techniques that go beyond the traditional nondestructive testing for internal flaw detection are presented in these proceedings. New diagnosis, prognosis and rehabilitation techniques applied to engineering structures made of metal, concrete, and composites, as well as biological systems are presented. The papers published here cover a wide range of technologies. It is hoped that this conference will stimulate further interactions between physical and life science communities resulting in newer development of more innovative techniques for health monitoring applications.

I am thankful to the program committee members, authors, session chairs, and the SPIE staff for putting together this excellent conference.

Tribikram Kundu 
Proc. of SPIE Vol. $9805980501-16$

Downloaded From: https://www.spiedigitallibrary.org/conference-proceedings-of-spie on 26 Apr 2023 Terms of Use: https://www.spiedigitallibrary.org/terms-of-use 